\title{
RELEVANSI MEDIASI PENAL DALAM PENERAPAN DIVERSI KASUS ANAK
}

\author{
Ahmad Syakirin \\ Fakultas Syariah IAIN Ponorogo \\ a.syakirin@gmail.com
}

ABSTRACT: Law on the juvenile justice system No. 11 of 2011 limits the age at which children can be subject to sanctions, both in the form of criminal sanctions and actions. In all matters, the handling of this child's problem will get different priorities when compared to adults in general. Starting from the investigation, prosecution, and trial the series will look different, this is a consequence of the implementation of lex specialists (lex specialis legi superior). The concept of this juvenile criminal justice system is essentially the whole process of solving cases related to children that considers the law, starting from the investigation stage to the guidance stage after undergoing punishment. So, the concept of penal mediation is very relevant in all problems related to the world of children, by promoting the ideas of the peace process as an effort to resolve child criminal cases outside the court.

\section{Keywords: Penal Mediation, Diversion, Juvenile Justice System (SPPA).}

ABSTRAK: Undang-undang sistem peradilan pidana anak no 11 tahun 2011 memberi batasan terhadap usia kapan anak bisa dikenai sanksi, baik berupa sanksi pidana ataupun tindakan. Dalam segala hal terkait penanganan anak ini akan mendapatakan prioritas yang berbeda bila dibandingkan dengan orang dewasa pada umumnya. Mulai dari penyidikan, penuntutan, dan persidangan rangkaiannya akan nampak beda, hal demikian akaibat sebagai konsekwensi terhadap implementasi lex spesialis (lex specialis legi superior). Konsep sistem peradilan pidana anak ini (Juvenile Justice System) hakikatnya adalah keselurahan proses penyelesaian perkara berkaitan anak yang berhadapan dengan hukum, dimulai dari tahap penyelidikan sampai dengan tahapan pembimbingan setelah menjalani pemidanaan. Jadi, konsep mediasi penal ini sangat relevan dalam menangani segala permasalahn terkait dengan dunia anak, dengan megedepankan ideide proses perdamaian sebagai upaya mengedepakan penyelesaian perkara pidana anak diluar pengadilan.

Kata kunci: Mediasi Penal, diversi, Sistem Peradilan Anak (SPPA). 


\section{PENDAHULUAN}

Anak adalah amanah sekaligus karunia Tuhan Yang Maha Esa, yang senantiasa harus kita jaga karena dalam dirinya melekat harkat, martabat, dan hak-hak sebagai manusia yang harus senantiasa dijunjung tinggi. Hak asasi anak merupakan bagian dari hak asasi manusia yang termuat dalam pasal 28 B UUD $1945^{1}$ dan Konvensi PBB Tentang Hak Anak. Dalam sisi kehidupan berbangsa dan bernegara, posisi anak merupakan suatu harapan masa depan dan generasi penerus cita-cita bangsa ini, sehingga setiap anak mempunyai hak atas kelangsungan hidup, tumbuh, dan berkembang, serta berhak atas perlindungan negara dari setiap tindakan kekerasan dan diskriminasi yang akan menimpah anak.

Pemidanaan bukan merupakan tujuan akhir dan bukan pula merupakan satu-satunya cara untuk mencapai tujuan pidana. Banyak cara dapat ditempuh, baik mengunakan sistem peradilan pidana anak maupun dengan cara di luar hukum pidana atau penanganan diluar pengadilan. Dilihat dari segi sejarah sistem peradilan pidana disamping tidak efisien, juga menghidari kekakuan dalam praktik penerapan hukum yang selama ini sakral. ${ }^{2}$

Adanya kekhususan relatif baru sebagaimana dalam undangundang sistem peradilan pidana anak (SPPA) tersebut melahirkan perbedaan dalam memperlakukan anak ataupun proses pemidanaannya.

Bahwa Indonesia sebagai negara pihak dalam Konvensi HakHak Anak (Convention on the Rights of the Child3) yang mengatur prinsip perlindungan hukum terhadap anak mempunyai kewajiban untuk memberikan perlindungan khusus terhadap anak yang berhadapan dengan hukum. Pembaharuan sistem peradilan pidana anak dengan mengintegrasikan mediasi penal perlu dilakukan untuk mewujudkan sistem peradilan yang progresif dengan tetap berlandaskan pada nilai-nilai luhur pancasila.

\footnotetext{
1 UUD 1945 pasal 28 B

${ }^{2}$ Paulus Hadi Suprapto, Peradilan restorative: Model Peradilan Anak di Indonesia masa Mendatang, (Malang: Bayu Media, 2008), hal. 68

3 Yaitu KHA (Konvensi Hak Anak/convention on the right of the child) sebagai Negara yang ikut meratifikasi wajib menerapkan kaidah hukum dalam dokumen konvensi dengan melakukan harmonisasi huskum.
} 
Dalam sejarah, teori absolut merupakan teori penjatuhan hukman yang sangat tua kurun waktunya. Teori ini memberi pandangan bahwa pembalasan terhadap setiap pelaku kejahatan yang setimpal dengan apa yang dilakukan. Meskipun kecenderungan untuk membalas ini pada prinsipnya adalah suatu gelaja yang normal, akan tetapi pembalasan tersebut harus dilihat sebagai suatu reaksi keras yang bersifat emosional dan karena itu irrasional ${ }^{4}$.

Dalam konsep teori absolute/retributive ini misalnya, memandang bahwasanya pemidanaan merupakan suatu bentuk pembalasan atas kesalahan atau perbuatan yang telah dilakukan. Jadi dalam teori ini sangatlah jelas berorientasi pada perbuatan dan terletak pada terjadinya kejahatan itu. Model teori pembalasannya ini memang berpandangan pada masa-mas lampau, yaitu memusatkan argumentasinya pada suatu kejahatan yang sudah dilakukan.

Ide-ide tentang konsep pembaruan hukum pidana (penal reform) menjadi dasar utama terbentukan konsep pandangan kebijakan mediasi penal, yang mana upaya penyelesaian selama ini selalu berkutat pada prosedur baku (kaku) terhadap pandangan bahwa hokum itu mempunyai sikap yang sacral dan tidak bisa diganggu gugat dan lebih bersifat pragmatisme. Tentu banyak ideide yang melatar belakngi kebijakan "penal reform' yaitu antara lain ide perlindungan korban, ide harmonisasi, ide restorative justice, ide mengatasi kekakuan/formalitas hukum, ide untuk menghindari efek negatif dari sistem peradilan pidana dan system pemidanaan yang ada saat ini, terutama dalam mencarai alternatif lain dari pidana penjara (alternative to imprisonment/alternative to custody).

Praktik penyelesaian perkara terutama kausus yang berhubungan dengan pidana atau diluar pengadilan selama ini memang selama ini tidak mempunyai landasan hukumnya yang kuat/landasan formalnya, sehingga kerap terjadi kasus yang secara informal sudah jelas ada fakta-fakta penyelesaian (mekanisme adat), akan tetapi tetap ditindak lanjuti dalam proses pengadilan sesuai fakta hukum yang berlaku kerena keterbatasannya pengetahuan dalam bidang ilmu hukum tentunya.

4 Sholahuddin, Sistem Sanksi Dalam Hukum Pidana (Ide Dasar Double Track System dan Implementasinya, (Jakarta: Rajawali Citra,2004), 34 
Salah satu hal kritik yang mencuat adalah dalam proses penerapan hukum pidana yakni lebih mengedepapankan dari sisi formalitas yang mana cenderung bersifat represif serta kurang humanis (rasa kemanusiannya) posisi pelaku kejahatan, sehingga sangat terkesan bahwasnya hukum pidana identik sebagai sarana pembalasan. Maka, cara yang paling baik ditembuh adalah melalui jalan mediasi, yang nantinya mewujudkan suatu kesepakatan bersama jalan damai yang kemudian ditandai suatu akta kesepakatan perdamaian antara kedua belah pihak dan ini nantinya akan disebut sebagai prosedur mediasi penal, apalagi disini pelakunya adalah seorang anak. Hukum Pidana (teori retributif) dalam perkembangannya mulai banyak menuai kritik karena dinilai sangat kaku dalam penerapannya dan terkadang kurang menyentuh sisi-sisi keadilan yang ada ditengah masyarakat.

Dalam praktik internasional jelas telah diakui bahwasanya tujuan penyelenggaraan sistem peradilan pidana anak ini lebih ditekankan mengutamakan akan segala hal kepentingan pada anak. Konsep peradilan pidana anak atau lebih dikenal dengan Juvenile Justice System merupakan salah satu bentuk perlindungan yang diberikan hukum kepada anak yang melakukan tindak pidana/berhadapan dengan hukum. Tujuan yang paling utama dari sistem peradilan ini telah ditegaskan dalam regulasi perserikatan bangsa-bangsa, yakni dalam SMR-JJ (Standard Minimum Rules For The Administration Of Juvenile Justice System/Beijing Rules) $)^{5}$ menegaskan bahwa orientasi dari keseluruhan proses peradilan pidana anak harus ditujukan dan dilandasi prinsip dasar kepentingan terbaik untuk anak (The Best Interest For Children).

Barda Nawawi memberi pandangan dalam menjalankan prinsip-prinsip Beijing rule/smr-jj yakni jelas mengatur juga tentang pemberian-pemberian kewenangan seluruh aparat penegak hukum untuk seyogyanya bisa mengambil langkah-langkah bijak dalam menangani atau menyelesaikan masalah pelanggaran anak dengan tidak mengambil jalan formal, antara lain menghentikan atau tidak meneruskan/melepaskan dari segala proses peradilan, mengambil upaya penyelesaian berdasarkan kesepakatan bersama antar berbagai pihak atau yang sering disebut mediasi yang mana salah

${ }^{5}$ Resolusi PBB 40/33 tanggal 29 November 1985 dalam rule 11 dan 17.4 
satu hasilnya nanti bisa berbagai wujud penerapan jenis-jenis program diversi. ${ }^{6}$

Dengan adanya kesepakatan dari berbagai pihak ini, sehingga mendapatkan apa yang dinamakan mediasi penal yang berupa penetapan yang mempunyai kekuatan hokum yang sesuai dengan prinsip dan amanat undang-undang no. 11 Tahun 2012 Tentang Sistem Peradilan Pidana Anak, penerapan yang berupa hasil diversi ini bisa mengahasilkan penyerahan kembali kepada orang tuanya, upaya perdamaian dengan atau tanpa ganti rugi, bimbingan/conseling, ikut serta dalam upaya pendidikan/pelatihan di lembaga pendidikan atau LPKS.

Sistem peradilan pidana (Criminal Justice System) merupakan sistem (jaringan/network) peradilan yang mengaplikasiakan hukum pidana sebagai sarana utama, yakni baik hukum pidana subtansial, hukum pidana formal, maupun hukum pelaksanaan pidana secara terintegral. Konsep sistem peradilan pidana anak ini (Juvenile Justice System) hakikatnya adalah keselurahan proses penyelesaian perkara berkaitan anak yang berhadapan dengan hukum, dimulai dari tahap penyelidikan sampai dengan tahapan pembimbingan setelah menjalani pemidanaan 7 .

Sistem peradilan pidana anak adalah suatu proses penyelesaian perkara anak yang berhadapan dengan hukum mulai dari tahap menyidikan sampai dengan tahan pembimbingan setelah menjalani proses pidana yang berdasarkan perlindungan, keadilan, non diskriminasi, kepentingan terbaik bagai anak, pengahargaan terhadap anak, kelangsungan hidup dan tumbuh kembang anak, proporsional, perampasan kemerdekaan, dan pemidanaan sebagai bentuk upaya terakhir dan menghindari balasan (Pasal 1 Angka 1 Undang-Undang No. 11 Tahun 2012 Tentang Sistem Peradilan Pidana Anak) $)^{8}$.

\footnotetext{
2009), Hal. 70

7 Barda Nawawi Arif, Perkembangan Sistem Pemidanaan Di Indonesia. (Semarang: Pustaka Magister, 2007), Hal. 2

8 Dalam UU SPPA sebagai penggati UU No 3 Thn 1993 lebih komprehensip dalam menelaah maupun merevisi sebagai bukti regulasi ini memberikan paung hukum terhadap anak yang berhadap dengan hukum. Selain itu, merupaka bentuk relevansi yang sangat cocok dalam menerapkan model pembaruan hukum yang tidak terkualia dalam bidang anak.
}

6 Setyo Wahyudi, Diversi Dalam Sistem Peradilan Pidana Anak, (Semarang: UNDIP, 


\section{Relevansi mediasi penal dalam sistem peradilan pidana anak}

Idea tau gagasan yang melatarbelakangi tentang konsep pembaruan hokum pidana (penal reform) menjadi dasar utama terbentukan konsep pandangan kebijakan mediasi penal, yang mana upaya penyelesaian selama ini selalu berkutat pada prosedur baku (kaku) terhadap pandangan bahwa hukum itu mempunyai sikap yang sacral dan tidak bisa diganggu gugat dan lebih bersifat pragmatisme. Tentu banyak ide-ide yang melatar belakngi kebijakan "penal reform' yaitu antara lain ide perlindungan korban, ide harmonisasi, ide restorative justice, ide mengatasi kekakuan/formalitas hukum, ide untuk menghindari efek negatif dari sistem peradilan pidana dan system pemidanaan yang ada saat ini, terutama dalam mencarai alternatif lain dari pidana penjara (alternative to imprisonment/alternative to custody). ${ }^{9}$

Hal yang baru lahir adalah dengan adanya penambahan uraian mediasi penal sehubungan telah dikeluarkannya uu no. 11/2012 tentang SPPA. Jelas sudah, bahwasanya uu ini dimaksudkan sebagai pengganti uu no 3/1997 tentang Pengadilan Anak yang dinilai belum secara komprehensip mencerminkan usaha-usaha rasa keadilan yang terbaik untuk anak.

Sebagai Subtansi yang paling mendasar dalam uu tersebut adalah terkait pengaturan secara tegas menegenai keadilan restroratif (ps. 1 (6)) terhadap anak yang berhadapan dengan hukum. Kemudian secara eksplisit jelas bahwa uu ini memberikan ruang baru bagi para penegak hukum, keluarga dan masyarakat dimana wajib mengupayakan segala proses penyelesaian dilaksanakan diluar pengadilan dalam kasus anak melalui jalur diversi berdasarkan suatu model pendekatan keadilan restroratif. Maka bahwasanya implementasi 'mediasi penal' terkesan sangat kuat didakam uu sppa ini., sekalipun dalam hal ini tidak secara terang-terangan menggunakan istlah mediasi. ${ }^{10}$

UU Sppa ini memberikan sinyal kuat tentang adanya praktik model mediasi penal, yang nampak pada ketentuan umum uu sppa dengan istilah restorative justice atau diversi yang mana ruh hakikatnya adalah tentang pelaksanaan mediasi. Seperti telah

9 Barda Nawawi Arif, Perbandingan Hukum Pidana. (Jakarta: Raja Grafindo, 2006), Hal. 107

10 Barda Nawawi Arif, Mediasi Penal: Penyelesaian Perkara Pidana Diluar Pengadilan. (Semarang: Pustaka, 2012) kata pengantar iii 
diuraikan pada bab-bab diatas menjelaskan bahwa bahsa mediasi ini seolah-olah mencerminkan hanya dalam skup keperdataan yang tidak banyak dikenal dalam Kontek hukum pidana. Hal demikian akan menimbulkan berbagai interprertsi public dalam menyikapi terutama mereka yang tidak memahami hukum secara penuh yakni mengartikan bahwa peraturan pidana saat ini telah mewenangkan praktik mediasi atau jalan damai. Hal inilah yang patut untuk dijelaskan, bahwa yang dimaksud mediasi dalam hal ini adalah bersifat terbatas dalam bidang ada anak yang berkonflik hukum bukan masuk secara komprehensif dalam bidang hukum pidana komprehensif akan tetapi hanya seputar batasan lex spesialais (lex specialis derogate legi generalis) yaitu uu sppa seperti apa yang kita lihat sekarang ini.

Sifat pemehaman yang parsial ini (setengah-setengah) sudah barang tentu akan membahayakan pada semua lapisan, tak terkecuali penegak hukum. Konseksennya tentu akan membawa akibat yang fatal pada setiap pengambilan sebuah keputusan nanti yang justru menjadi bomerang yang mana mediasi penal bisa dipraktikan dalam masalah-masalah kajian pidana. Tentu hal ini akan menambah catatan buruk sekiranya para pihak tidak memiliki pemahaman luas dalam konteks apa pelaksanaan mendiasai penal ini bisa diterapkan.

Prof Barda nawawi Arif, memberi beberapa tanggapan tentang penggunaan istilah restorative justice adalah sebagai metode pendekatan atau upaya prosedur pembaruan dalam bidang hukum yang mana tidak dipandang kaku seperti pandangan hukum pidana klasik warisan Belanda, dan mempunyai pandangan terhadap model hukum yang akan datang (ius contuendum). Sedangkan istilah diversi menurut beliau adalah proses pengalihan suatu perkara anak dari proses peradilan pidana untuk dibawa kearah luar pidana atau kebijakan alternative improsemen/alternatife to custody. Hanya saja dalam teori diversi ini tetap memperhatikan syarat-syarat bagaimana mendapatkan/menghasilkan sebuah kesepakatan yang nanti akan lebih dikenal sebagai kesepakatan diversi ${ }^{11}$ 
Oleh karena itu pelaksanaan sistem peradilan pidana anak seyoganya dilaksanakan berdasarkan asas-asas sebagaimana terdapat dalam uu sppa seperti berikut: ${ }^{12}$
a. pelindungan;
b. keadilan;
c. nondiskriminasi;
d. kepentingan terbaik bagi Anak;
e. penghargaan terhadap pendapat Anak;
f. kelangsungan hidup dan tumbuh kembang Anak;
g. pembinaandan pembimbingan Anak;
h. proporsional;

i. perampasan kemerdekaan dan pemidanaan sebagai upaya terakhir; dan

j. penghindaran pembalasan.

Sehingga perlu ditegaskan bahwa untuk menjaga harkat dan martabatnya, anak berhak mendapatkan pelindungan khusus, terutama pelindungan hukum dalam sistem peradilan. Sebagai konsekwensinya adalah Indonesia sebagai negara pihak dalam konvensi hak-hak anak (Convention on the Rights of the Child) ${ }^{13}$ yang mengatur prinsip pelindungan hukum terhadap anak mempunyai kewajiban untuk memberikan perlindungan khusus terhadap anak yang berhadapan dengan hokum.

\section{Peran Bapas}

Hal terpenting disni adalah akan peran bapas yang paling sangat menentukan dalam mempengaruhi jalannnya prosedur sistem peradilan anak. Baik nanti proses akan dilanjut atau tidak akan menentukan posisi masa depan anak. Prosedur demikian menjadi ciri khas yang ada dalam system peradilan anak yang tidak baka ditemukan pada peradilan orang-orang dewasa. Jadi, yang dimaksud dalam prosedur ini adalah bapas memberikan masukan ataupun saran, pertimbangan, dalam upaya diversi pada setiap lini proses hukum, baik pada ingkat penyidikan, penuntutan, ataupun pada persidangan. Jalannya proses bapas (yang dijalankan

\footnotetext{
12 Asas-asas yang harus dilaksanakan sebagaimana termuat dalam pasal 2 UU SPPA.

13 Keppres No 36 Tahun 1990 tentang pengasahan konvensi tentan anak, sebagai konsekwensinya meratifikasi konvensi tersebut adalah membuat kebijakan aturan tentang anak.
} 
pembimbing kemasyarkatan) dalam memberikan arahan wajib diberikan, dan sebagai konsekwensi terhadap pengesampingan masukan ataupun arahan yang dikeluarkan lembaga ini akan berdapak pada proses hukum selanjutnya, yakni bisa dikatankan batal demi hukum sekalipun tidak dimintai prosedur pembatalan.

Bapas adalah salah satu pihak yang terlibat selama proses peradilan Anak yang berkonflik dengan hukum dari awal anak ditangkap hingga anak menyelesaikan masa hukumannya. Ha lini membuat bapas memiliki peran yang penting dalam proses peradilan Anak yang berkonflik dengan hukum. ${ }^{14}$ Secara umum peran bapas dalam proses peradilan Anak yang berkonflik dengan hukum terbagi menjadi 3 tahap, yaitu tahap sebelum sidang pengadilan (praajudikasi) yakni penyidikan, tahap saat siding pengadilan (adjudikasi) yakni pendampingan dipersidangan dan tahap setelah pengadilan (postadjudikasi) yakni pengawasan dan pembimbingan bagi Anak yang berkonflik dengan hukum. ${ }^{15}$

Dalam uu pemasyarakatan, abapas mempunyai tugas pokok yakni memberikan bimbingan dan pengawasan terhadap klien pemasyarakatan. Termsauk disini adalah fungsi bapas adalah sebagai pelaksanaan tugas, yaitu yang secara khusus ditugaskan pada pembimbing kemasyarakatan yakni melakukan penelitian kemasyarakatan (litmas) untuk memperlancar tugas penyidikan, penuntutan, dan hakim dalam perkara anak (case report), menentukan program pembinaan nara pidana dan anak didik

${ }^{14}$ Sementara Moeljatno menggunakan istilah reklasering, dalam pasal 16 ayat 1 dan 2 KUHP: "Menurut Sudarsono pengertian reklasering adalah “Langkah/tindakan pengembalian kepada masyarakat atau kepada kehidupan yang biasa misalnya dengan mengawasi orang yang dihukum dengan syarat memberi bantuan kepada orang-orang yang baru keluar dari Lembaga Pemasyarakatan ( LP )". Secara normatif, keberadaan Balai Pemasyarakatan baru disebutkan dalam Undang-Undang Nomor 12 Tahun 1997 tentang Pemasyarakatan. Meskipun begitu, sebenarnya lembaga sejenis sebelumnya telah ada, namun dengan nama Balai Bimbingan Kemasyarakatan dan Pengentasan Anak (Bispa). Bahkan jauh sebelum proklamasi kemerdekaan, pelaksanaan sebagian dari fungsi-fungsi lembaga tersebut telah ada, yakni dilaksanakan oleh lembaga lain yang tergabung dalam lembaga kepenjaraan saat itu bernama "Gevangenis Tucht, Opvuding, Reclaseering \& Armwezen" atau disingkat "Gevangeniswezen \& TORA" (Kepenjaraan, Reklasering, dan Urusan-urusan Orang Miskin). Istilah reklasering inilah yang lama kelamaan menjadi cikal bakal pendirian Balai Pemasyarakatan. Reklasering berasal dari bahasa Belanda yakni "reclasseering" yang berarti pemulihan kembali.

15 Nashriana, Perlindungan Hukum Pidana Bagi Anak Di Indonesia, (Depok: Raja Grafindo Persada, 2012), Hlm. 110-116. 
pemasarakatan dilapas anak (LPKA)menentukan program perawatan, bimbingan, serta pengawasan, terhadap terpidnana anak, yang dijatuhi pidana pengawasan yang telah diserahkan pada orang tua/wali/orang tua asuh. ${ }^{16}$

Hasil penelitian menunjukkan bahwa tugas Balai Pemasyarakatan adalah untuk melakukan penyembuhan dan rehabilitasi serta resosialisasi terhadap pelanggar hukum agar mampu menyesuaikan diri kembali dalam hidup bermasyarakat. Kendala yang menghambat pelaksanaan dalam melakukan bimbingan adalah kurangnya sarana dan prasarana serta biaya operasional yang minim kepada Balai Pemasyarakatan dalam menjalankan peran dan fungsinya. usaha yang dilakukan diantaranya mengikuti bimbingan dan pengarahan dari Kepala Balai Pemasyarakatan, dan bekerja sama dengan instansi lain seperti Dinas Sosial, Kepolisian, dan Kejaksaan ${ }^{17}$.

\section{Mediasi Penal Sebagai wujud Pelaksanaan Model Konsep Pembaruan Hukum Di Indonesia}

Ide-ide tentang konsep pembaruan hukum pidana (penal reform) menjadi dasar utama terbentukan konsep pandangan kebijakan mediasi penal, yang mana upaya penyelesaian selama ini selalu berkutat pada prosedur baku (kaku) terhadap pandangan bahwa hukum itu mempunyai sikap yang sacral dan tidak bisa diganggu gugat dan lebih bersifat pragmatisme. Tentu banyak ideide yang melatar belakngi kebijakan "penal reform' yaitu antara lain ide perlindungan korban, ide harmonisasi, ide restorative justice, ide mengatasi kekakuan/formalitas hukum, ide untuk menghindari efek negatif dari sistem peradilan pidana dan sistem pemidanaan yang ada saat ini, terutama dalam mencarai alternatif lain dari pidana penjara (alternative to imprisonment/alternative to custody). ${ }^{18}$

16 Dr. Eva Achany Ulfa dkk, Perkembangan Sistem Pemidanaan Dan Sistem Pemasyarakatan, (Jakarta: Raja Wali Press, 2009), Hal. 45

17 Pergeseran UU tentang bapas tersebut sebagai jawaban atas disyahkannya UU pengadilan anak pada waktu itu. Hal ini karena penanganan anak memberikan beban tugas dalam pelaksananaan uu pengadilan anak.

18 Ibid, hal 1 
Kajian pragmatism ini bertujuan untuk melatarbelakangi untuk mengurangi stagnasi atau banyaknya penumpukan perkara "the problem of court case overload", yang akan mempermudah dalam penyederhanaan prosedur peradilan yang selama ini menjadi masalah serius dalam penanganan dan penyelesaian suatu kasus. Walaupun pada kenyataannya penyelesaian sengketa diluar pengadilan hanya terdapat dalam sengketa-sengketa perdata, namun tidak menutup kemungkinan kasus yang berhungan dengan pidana juga kerap diselesaikan darena luar pengadilan melalui upaya diskresi aparat penegak hukum ataupun melalui berbagai mekanisme jalan musyawarah/perdamaian/permaafan bahkan penyelesaian tata cara adat. ${ }^{19}$

Dalam perkembangan wacana-wacana secara teoritik maupun perkembangan dalam pembaruan hukum pidana diberbagai belahan negara, bahwasanya ada kecenderungan kuat dalam memakai sarana mediasi pidana/penal yakni sebagai salah satu bentuk sarana alternatif menyelesaikan permasalahan yang kompleks dalam kajian/bidang hukum pidana.

Sebagai Subtansi yang paling mendasar dalam uu tersebut adalah terkait pengaturan secara tegas menegenai keadilan restroratif (ps. 1 (6)) terhadap anak yang berhadapan dengan hukum. Kemudian secara eksplisit jelas bahwa uu ini memberikan ruang baru bagi para penegak hukum, kelurga dan masyarakat dimana wajib mengupayakan segala proses penyelesesian dilaksanakan diluar pengadilan dalam kasus anak melalui jalur diversi berdasarkan suatu model pendekatan keadilan restroratif. ${ }^{20}$

Undang-undang sppa ini memberikan pandang yang progresif tentang adanya praktik model mediasi penal, walaupun dalam uu tersebut belum secara tegas menggunakan istilah mediasi. Kontribusi subtansial yang tersirat ataupu tersurat dalam aturan sppa mencerminkan sebuah pembaruan yang lebih luas ke model-model yang melenceng dari pendahulunya, yakni kuhp yang belum

19 Endrik Safudin, Politik Hukum Diskresi di Indonesia, (Ponorogo: LPPM IAIN Ponorogo, 2019), Hal. 84

Dengan jumlah penduduk yang banyak jaga turut melahirkan angka kejahatan yang banyak juga, maka dari kasus-kasus tersebut sering melahirkan diskresi dalam hukum pidana guna mempercepat kasus-kasus yang orientasi ringan problemnya.

20 Barda Nawawi Arif, Mediasi Penal: Penyelesaian Perkara Pidana Di Luar Pengadilan, ( Semarang: Pustaka Magister, 2012), hal. 2 
terilhami sama sekali. Hal ini tentu akan membuka dua cara pandang dalam hukum pidana, yang pertama adalah cara pandang yang kaku dan yang kedua cara pandang yang fleksibel. Uu sppa inilah yang nantiya bisa diangap sebagai cikal bakal pembaruan hukum pidana yang mengenalkan model cara mediasi atau ADR/alternative dispute resolution) dalam penyelesaian malasah tindak pidana anak, hal demikian sangat berguna dengan wacana hukum modern saat ini seperti menghindari kekakuan/absolutifme dalam pemidanaan dan tidak pula dilupakan sebagi bentuk koreksi judicial terhadap asas legalitas (judicial corrective to the legality principle) $)^{21}$

Mediasi penal merupakan salah satu bentuk alternatif penyelesaian sengketa di luar pengadilan (yang biasa dikenal dengan isti-lah ADR atau "Alternative Dispute Reso-lution"; ada pula yang menyebutnya "Apro-priate Dispute Resolution" 22). ADR pada umumnya digunakan di lingkungan kasus-kasus perdata ${ }^{23}$, tidak untuk kasus-kasus pidana. Berdasarkan perundang-undangan yang berlaku di Indonesia saat ini (hukum positif) pada prinsipnya kasus pidana tidak dapat diselesaikan di luar pengadilan, wa-laupun dalam hal-hal tertentu, dimungkinkan adanya penyelesaian kasus pidana di luar pengadilan.

Praktek penyelesaian perkara pidana di luar pengadilan selama ini tidak ada landasan hukum formalnya, sehingga sering terjadi suatu kasus yang secara informal telah ada penyelesaian damai (walaupun melalui mekanisme hukum adat), namun tetap saja diproses ke pengadilan sesuai hukum yang berlaku.

Dalam perkembangan wacana teoritik mau-pun perkembangan pembaharuan hukum pidana diberbagai negara, ada kecende-rungan kuat untuk menggunakan mediasi pidana/penal sebagai salah satu alternatif penyelesaian masalah di bidang hukum pidana. Menurut Prof. Detlev Frehsee, meningkatnya penggunaan restitusi dalam proses pidana menunjukkan, bahwa perbedaan antara hukum

${ }^{21}$ Barda Nawawi Arif, RUU KUHP BARU: Sebuah Restrukturisasi Sistem Hukum Pidana Indonesia, (Semarang: Pustaka Magister, 2008), hal. 1

${ }^{22}$ New York State Dispute Resolution Association, Inc., Alternative Dispute Resolution in New York State, An Overview, sbr internet.

${ }^{23}$ Lihat UU No. 30/1999 tentang Arbitrase dan Alternatif Penyelesaian Sengketa. 
pidana dan perdata tidak begitu besar dan perbedaan itu menjadi tidak berfungsi ${ }^{24}$.

Mediasi penal pastinya merupakan suatu bentuk wujud dimensi baru dari kajian aspek teoritik dan praktik. Kebijakan ini merupakan langkah konkret yakni sebagai upaya hukum yang tentunya tidak bisa dipandang sebelah mata, karena mempunyai atau diakui sah secara hukum tanpa menimbulkan rasa keraguan dan kekhawatiran akan kekuatan hukum dikemudian hari. Sehingga tentunya hal ini akan mengurangi volume jumlah perkara yang tidak semuanya harus benar-benar lari ke lembaga yang bernama pengadilan. Sehingga implementasi asas peradilan yang bersifat sederhana, cepat, dan biaya ringan akan benar terealisir tanpa harus mengorbankan tujuan peradilan, terutama dalam hal ini adalah masalah anak yang berhadapan dengan hukum.

Melalui proses mediasi penal maka diperoleh puncak keadilan tertinggi karena terjadinya kesepakatan para pihak yang terlibat dalam perkara pidana tersebut yaitu antara pihak pelaku dan korban. Pihak korban maupun pelaku diharapkan dapat mencari dan mencapai solusi serta alternatif terbaik untuk menyelesaikan perkara tersebut

Salah satu hal kritik yang mencuat adalah dalam proses penerapan hukum pidana yakni lebih mengedepapankan dari sisi formalitas yang mana cenderung bersifat represif serta kurang humanis (rasa kemanusiannya) posisi pelaku kejahatan, sehingga sangat terkesan bahwasnya hukum pidana identik sebagai sarana pembalasan. Contoh kasus sederhana, semisal tindak pidana perkelahian ataupun pencurian, sedangkan anak yang bersangkutan masih dibawah umur ini sering kali di meja hijaukan, oleh pandang masyarakat hal ini tidak layak utuk diperkarakan. Maka, cara yang paling baik ditembuh adalah melalui jalan mediasi, (relevansi inilah yang mendasari mediasi dianggap sebagai kebijakan tepat sesuai jiwa bangsa kita) yang nantinya mewujudkan suatu kesepakatan bersama jalan damai yang kemudian ditandai suatu akta kesepakatan perdamaian antara kedua belah pihak dan ini nantinya akan disebut

${ }^{24}$ Detlev Frehsee (Professor of Criminology and Criminal Law, University of Bielefeld, Germany), "Restitution and Offender-Victim Arrangement in German Criminal Law: Development and Theoretical Implications", http://wings.buffalo.edu/law/ bclc/bclr.htm 
sebagai prosedur mediasi penal, apalagi disini pelakunya adalah seorang anak.

Hukum Pidana (teori retributive atau pembalasan) dalam perkembangannya mulai banyak menuai kritik karena dinilai sangat kaku dalam penerapannya dan terkadang kurang menyentuh sisi-sisi keadilan yang ada ditengah masyarakat.

Karakteristik mediasi penal menekankan pada upaya nonformal, bukan suatu hal borokratis serta sangat menghidari formalitas hukum yang ada. Sehingga hal ini merupakan salah satu terobosan kebijakan alternatif sama kita asumsikan membuka katup/klep kran air yang tertutup kita pahami selama ini dalam pengetian konsep hukum pidana, inilah yang kemudian disebut sebagai ide permaafan hakim (Reterlijk Pardon) ${ }^{25}$.

Dalam pandangan hukum pidana (penal reform/lex specialis) para pihak bisa terlibat secara kompleks tidak membatasi dari pelaku, korban, pihak aparat kepolisian, kejaksaan, pemberi bantuan hukum, tokoh masyarakat/ulama, LBH, LSM, dan sebagainya mempunyai andil besar dalam upaya mencari jalan penyelesaian, inilah yang kemudian hari disebut kebijakan penalisasi dalam konteks wujud mediasi penal, anak yang seharus kena sanksi, menjadi mendapat pengesampingan berkat kebijakan mediasi yang diimplementasikan uu sppa).

Pendekatan mediasi penal kedalam sistem peradilan pidana di Indonesia dapat menciptakan hukum progresif yang menghendaki semua penyelesaian pelanggaran tidak didominasi oleh negara dengan mengesampingkan yang lain, temasuk monopoli penyelesaian sengketa oleh pengadilan. Pendekatan keadilan restoratif dalam hukum pidana memiliki kekuatan yang mampu memulihkan hubungan antar pihak yang menjadi pelaku dan yang korban. Proses mediasi didalam pelanggaran pidana dapat menjadikan pelaku tindak pidana bertanggung jawab memperbaiki kerugian yang ditimbulkan akibat kesalahannya dengan cara yang konstruktif. Dan disamping itu, pandangan konvensional masyarakat dan juga aparat penegak hukum atas penyelesaian hukum terhadap pelanggaran pidana yang masih memegang

${ }^{25}$ Hadi Supeno, Kriminalisasi Anak: Tawaran Gagasan Radikal Perailan Anak Tanpa Pemidanaan, (Jakarta: GRAMEDIA, 2010), 221. 
paradigma lama bahwa perkara pidana tidak dapat diselesaikan diluar proses pengadilan dapat dihilangkan dan diperbaharui menuju hukum yang mencipatakan harmonisasi sosial dan welfare state.

Hal lain juaga ditegaskan dalam instrument The Beijing Rule butir 11 yang mengatur tentang pengalihan (diversi) merupakan sebuah langkah kesepakatan internasional yang berperan dalam mempengaruhi kebijakan-kebijakan diseluruh negara didunia nantinya untuk melakukan pembaruan-pembaruan kebijakan perundang-undanganya guna memberikan perhatian khusus terhadap anak. Pada butir tersebut juga memberikan himbauan lebih seperti pengawasan, bimbingan sementara, pemulihan dan bahkan ganti rugi.

\section{Pelaksanaan Diversi Kasus Anak (diversi Berhasil \& Gagal)}

Diversi merupakan suatu bentuk pengalihan penyelesaian perkara Anak dari proses peradilan pidana ke proses di luar peradilan pidana. Diversi bagi tidak pelaku anak adalah untuk menyediakan alternatif yang lebih baik dibanding dengan prosedur resmi beracara di pengadilan. Program diversi sangat member keuntungan dalam penanganan awal dan cepat terhadap perilaku menyimpang yang mengubah cara pandang terhadap sistem yang selama hukum positif yang selama ini $\mathrm{ada}^{26}$.

Bahwa mestinya proses diversi mengutamakan kepentingan terbaik bagi anak, bukan hanya pengesampingan/perdamaian antara korban dengan anak. Selain itu proses diversi semestinya tidak terkungkung dengan batasan ancaman penjara dibawah 7 tahun. Pada prinsipnya sesuai dengan prinsip-prinsip hukum internasional, proses diversi haruslah mengutamakan kepentingan terbaik bagi anak. Walaupun demikian, UU SPPA membuka kemungkinan proses diversi terhadap tindak pidana yang dilakukan anak tanpa harus ada kesepakatan diversi apabila tindak pidana tersebut bersifat pelanggaran, bagian dari tindak pidana ringan, tindak pidana tanpa korban atau nilai kerugian korban tidak lebih dari nilai upah minimum provinsi setempat ${ }^{27}$.

${ }^{26}$ Ibid, Hlm 4. 57

27 Sebagaimana Perma No 2 tahun 2012 tentang penyesuaian batasan tindak pidan ringan dan jumlah denda dalam kuhp yang semula 250 menjadi 2500.000, hakim bias mengupayakan dilakukan perdamaian dengan tidak melanjut perkara tersebut. 
Hal lain yang patut populerkan adalah munculnya upaya hukum, yang berupa diversi. Dalam UU SPPA ini, diversi menjadi sesuatu yang wajib dilakukan pada penyidikan, penuntutan, dan hakim di pengadilan. Dalam kaca mata hukum model ini yang sangat baik untuk mendapatkan respon, karena sebagai pilihan alternatif dalam menghadapi kebuntuan hukum oleh para pejabat penegak hukum dari level kepolisian hingga ke pengadilan negeri. Namun memperkenalkan implementasi baru juga bukan merupakan sesuatu yang mudah tanpa mempunyai pendekatan keilmuan yang cukup luas.

Beberapa tujuan diversi dala uu sppa (sistem peradilan pidana anak) antara lain (ps.6):

1. Mencapai perdamainantara korban dan anak

2. Menyelesaikan perkra anak diluar proses peradilan

3. Menghindarkan anak dari perampasan kemerdekaan

4. Mendorong masyarakat untuk berpartisipasi

5. Menanamkan rasa tanggung jawabpada anak

Kesepakatan Diversi harus mendapatkan persetujuan korban dan/ataukeluarga anak Korban serta kesediaan Anak dan keluarganya. Akan tetapi, apabila hal-hal diatas tidak kunjung menuai kesepakatan, maka dapat dilakukan oleh penyidik bersama pelaku dan/atau keluarganya, Pembimbing Kemasyarakatan, serta dapat melibatkan tokoh masyarakat.

Hal-hal penting yang menjadi hasil kesepakatan diversi adalah (ps, 11 sppa):

1. Perdamaian dengan atau tanpa ganti kerugian

2. Penyerahan kembali kepada orang tua/wali

3. Keikutsertaan dalam pendidikan atau pelatihan di lembaga pendidikan/LPKS paling lama 3 bulan

4. Bentuk pelayanan kemasyarakatan

Proses peradilan pidana Anak dilanjutkan pada proses Diversi tidak menghasilkan kesepakatan atau kesepakatan Diversi tidak dilaksanakan. Kasus anak yang tidak menghasilkan kesepakatan diversi pada tingkat kepolisian serta setalah dilakukan pendekatanpendekatan oleh bapas mengalami jalan buntu, maka pihak kepolisian menlanjutkan hasil penyedikan dalam berita acara pemeriksaan, untuk kemudian dilanjutkan pada tahapan 
penuntutan, di pelajari dan diteliti kelengkapanya lagi sebagai dasar nantina untuk membuat surat dakwaan. ${ }^{28}$

Pengawasan atas proses Diversi dan pelaksanaan kesepakatan yang dihasilkan berada pada atasan langsung pejabat yang bertanggung jawab disetiap tingkat pemeriksaan. Selama proses Diversi berlangsung sampai dengan kesepakatan Diversi dilaksanakan, Pembimbing Kemasyarakatan wajib melakukan pendampingan, pembimbingan, dan pengawasan. Dalam hal kesepakatan Diversi tidak dilaksanakan dalsam waktu yang ditentukan,

Oleh karena itu, sangat diperlukan peran serta semua pihak dalam rangka mewujudkan hal tersebut. Proses itu harus bertujuan pada terciptanya keadilan restoratif, baik bagi anak maupun bagi korban. "Keadilan restorative" merupakan suatu proses implemntasi dari diversi, yaitu semua pihak yang terlibat dalam suatu tindak pidana tertentu bersama-sama mengatasi masalah serta menciptakan suatu kewajiban untuk membuat segala sesuatunya menjadi lebih baik dengan melibatkan korban, anak, dan masyarakat dalam mencari solusi untuk memperbaiki, rekonsiliasi, dan menenteramkan hati yang tidak berdasarkan pembalasan. ${ }^{29}$

UU Sistem Peradilan Pidana Anak merupakan cerminan amanat UUD 45 dan tertuang dalam Konvensi Tentang Hak-Hak Anak Resolusi PBB No. 109 Tahun 1990 yang telah diratifikasi dengan Keputusan Presiden No. 36 Tahun 1990. UU ini disusun dalam rangka mewujudkan tujuan "restorative justice" sebagai salah satu alternatif pelaksanaan pemidanaan bagi anak yang berkonflik dengan hukum. Didalamnya dinyatakan, penangkapan, penahanan, dan penghukuman/pemenjaraan harus menjadi langkah terakhir yang diambil dalam penanganan anak yang berkonflik dengan hukum (ultimum meredium) ${ }^{30}$ dan untuk jangka waktu yang paling pendek/waktu yang sesingkat-singkatnya.

Dalam Beijing Rules tentang administrasi peradilan bagi anak, persetujuan menempuh proses diversi berada pada anak yang berkonflik dengan hukum (pelaku) bukan pada korban. Dalam

28 Dr. Marliana, Peradilan Pidana Anak Di Indonesia; Pengembangan Konsep Diversi Dan Restorative Justice, (Bandung: Refika Aditama, 2012), 102

${ }^{29}$ Konsep keadilan Restoratif justice dalam UU SPPA No. 11 Tahun 2012, Pasal 1 (6 dan 7)

30 Sudarto, Hukum Pidana, (Semarang: Undip Pres, 1990), 13 
konteks diversi, korban dapat mengajukan syarat-syarat yang tentunya rasional dan terukur serta mempertimbangkan kepentingan terbaik bagi anak. Bahkan pembunuh sekalipun dimungkinkan dilakukan diversi.

Sebagai contoh adalah diversi, meski diversi telah diakui secara resmi sebagai bagian dari mekanisme keadilan restoratif, namun diversi dalam UU SPPA ini sangat mengedepankan faktor perdamaian antara korban tindak pidana dengan anak yang berhadapan dengan hukum.

Tetapi aturan di Indonesia masih belum mengikuti Beijing Rules. Sangat sayangkan hasil pembahasan Panitia Kerja RUU SPPA tertanggal 6 Februari $2012{ }^{31}$ bahwa keputusan diversi digantungkan kepada persetujuan korban. Artinya jika dalam proses upaya diversi korban tidak menyetujui maka aparat penegak hukum (polisi, jaksa, dan hakim) tidak dapat membuat keputusan diversi. Tentunya hal ini bertentangan dengan peraturan administrasi peradilan bagi anak (Beijing Rules).

Dengan menggunakan dan mengacu kepada uu sppa tersebut, kepolisian dapat menilai sendiri apakah suatu perkara yang ditanganinya tersebut pantas untuk dilanjutkan ke dalam penyidikan lalu ke pra penuntutan atau tidak. Jika perkara tersebut tidak pantas yang dalam hal ini adalah merupakan tindak pidana ringan seperti pelakunya adalah berusia anak-anak dan tentunya tidak menimbulkan efek kerugian dan biaya yang cukup besar, maka pihak kepolisian tersebut dapat menyelesaikannya lewat mediasi penal.

Dengan demikian dapat disimpulkan, bahwa kesepakat diversi ini bentuknya harus resmi yang berada pada tanggung jawab penuh oleh atasan masing tingkatan, dan yang dimaskud atas disini adalah kepala kepolisian, kepala kejaksaan, dan ketua pengadilan. ${ }^{32}$

31 RUU No.11/2012 tentang sistem peradilan pidana anak, ketika itu belum disyahkan dan baru tgl. 30 Juli 2012.

32 Dr Maya Indah s, Perlindungan Korban: Suatu Perspektif Viktimologi Dan Kriminologi (Jakarta: Kencana, 2014), 71

Sebagai catatan: hasil musyawarah ataupun mediasi ini tidak bisa dimuntakan penetapan pada setiap tingkatan kalu hal ini dilakuakan diluar petugas yang diamannahkan oleh undang-undang sppa. Misalna mereka harus ada petugas kemasyarakatan dari bapas, pendampingan dari keluarga dan atau tokoh masyarakat baik ulama, guru, dosen, dsb serta kedua belah pihak pelaku dna korban tanpa adanya rasa tekanan apapun. 
Tidak ada cara yang baik kecuali member kesempatan terbaik bagi anak, hampir setengah lebih penduduk indonseia ini didominasi oleh anak terutama mereka kebanyakan masih mengenyam dunia pendidikan yakni mulai tinkat SD, SMP, maupun SMA dan dimana meraka ini merpakan factor yang paling rentan dalam terjerumus dalam dunia kriminalitas.

Upaya diversi dengan cara pandang yang berdeda yakni tidak ada gunanya memberikan sanksi pada anak (terutama usia 14-18) dan justru akan memperparah nasib dan masa depan anak itu sendiri. Memang hal ini delema dalam kontek hukum pidana yang tidak mengenal istilah perdamaian/mediasi, akan tetapi lebih pada istilah keadilan restoratif (restorative justice) yang kurang familier ditelinga masyarakat yang lebih terbiasa dengan bahasa mediasi, hal inilah adalah sebuah amanat besar dalam implementasi uu sppa, 33

$\mathrm{Uu}$ sppa merupakan cerminan sebuah konsep pembaruan hukum khususnya dalam materi hukum pidana yang selama ini dikenal sebagai pedang bermata dua ${ }^{34}$. Dengan dicabutnya pasal 45, 46, 47 dalam KHUP member angin segar dalam perubahan-peruabahan dalam dunia hukum pidana yang diharapkan bisa menyentuh pada jiwa ketimuran dalam mengimplementasikan kemudian hari undagundang yang mewakili adat bangsa sejatinya.

Adapun substansi yang diatur dalam UU SPPA antara lain mengenai penempatan anak yang menjalani proses peradilan dapat ditempatkan di Lembaga Pembinaan Khusus Anak (LPKA). Substansi yang paling mendasar dalam Undang-Undang ini adalah pengaturan secara tegas mengenai Keadilan Restoratif dan Diversi yang dimaksudkan untuk menghindari dan menjauhkan anak dari proses peradilan sehingga dapat menghindari stigmatisasi terhadap anak yang berhadapan dengan hukum dan diharapkan anak dapat kembali ke dalam lingkungan sosial secara wajar.

33 Terdapat penerapan bahasa atau istilah anatar resoratife justice vs mediasi, kedua mempunyai makna yang sama dalam pengimplementasiannya. Hal ini sebagaimana tersirat dalam buku beliau prof, barda tentang mediasi penal: penyelesaian perkara pidana diluar pengadilan, tepatnya pada kata pengantar buku beliau (2012) hlm iii, namun kedua istilah tersebut adalah sama maknanya.

34 Sudarto, hukum pidana 1. (Semarang: Yayasan Sudarto, 1990) 13 Ad: istilah pedang dua artinya di satu sisi hukum (pidana) memberikan perlindungan, bagi siapa saja karena Negara member jaminan melalaui hadirnya sebuah undang-undang tersebut dan disisi lain memberikan sanksi yang tegas bagi pelakunya. 
Demikian antara lain yang disebut dalam bagian Penjelasan Umum UU SPPA.

Keadilan Restoratif merupakan suatu proses Diversi, yaitu semua pihak yang terlibat dalam suatu tindak pidana tertentu bersama-sama mengatasi masalah serta menciptakan suatu kewajiban untuk membuat segala sesuatunya menjadi lebih baik dengan melibatkan korban, anak, dan masyarakat dalam mencari solusi untuk memperbaiki, rekonsiliasi, dan menenteramkan hati yang tidak berdasarkan pembalasan. Diversi adalah pengalihan penyelesaian perkara anak dari proses peradilan pidana ke proses diluar peradilan pidana, sehingga, sanksi atas perbuatan anak dapat dialihkan (dikesampingkan) setelah memenuhi syarat dan upaya mediasi yang menghasilkan kebijakan diversi ${ }^{35}$.

Berikut kami rangkum hal-hal penting yang diatur dalam UU SPPA:

\section{Definisi Anak di Bawah Umur}

Sebelum lahirnya uu ini masalah pengaturan anak pada awalnya terdapat dalam kuhp akni pada pasal 45, 46, dan 47 yang mengatur jelas tentang sanksi pada anak yang melakukan tindak pidana.

Karena konsekwensi akan ratifikasi konvensi anak sedunia yang memberikan konsekwensi kepada semua Negara yang ikut mengaharuskan mempunyai aturan/ kebijakan/ instrument atautun undang-undang yang mengatur anak, diantaranya mengenai batas usia. Penentuan batas usia pada anaka ini diserahkan sepenuhnya pada negara yang bersangkutan. Jadi, disini jelas bahwa masalah perbedaan usia disetiap negara tidak sama dan tidak menjadi soal tergantung akan sebuah kebijakan pada setiap negara masing-masing.

Pada uu no 3 tahun 1997 tentang pengadilan anak batas usia adalah 8 sampai dengan 18 tahun, dengan ketentuan pada usia 8 sampai dengan 12 hanya dikenai tindakan, dan selanjutnya usia 12 sampai dengan 18 tahun dapat dikenai sanksi pidana. Dari undang-undang itu dapat diketahui tentang batasan usia seorang anak dapat dijatuhi sanksi.

Hadirnya undang-undang sistem peradilan pidana anak (SPPA) hal yang baru, yaitu mengenai ditambahnya batas usia

35 Setyo wahyudi, Diversi: 60 
pertanggungjawaban anak menjadi $12 \mathrm{~s} / \mathrm{d} 14$ tahun untuk dikenai tindakan dan $14 \mathrm{~s} / \mathrm{d} 18$ tahun untuk tindak pidana penjara.

\section{Penjatuhan Sanksi}

Sanksi yang termuat dalam kuhp sebelum aturan anak ada dalam aturan lex spesialis ini adalah memerintakan untuk diserahkan kembali kepada orang tuanya, atau walinya atau bisa kepada pemerintah.

Kemudian dalam undang-undang no 3 tahun 1997 memunculkan sanksi sebagai implementasi double track system yakni sanksi pidana dan tindakan, atau bisa dikembalikan pada orang tuanya jika anak tersebut usianya kurang dari 8 tahun.

Menurut UU SPPA, seorang pelaku tindak pidana anak dapat dikenakan dua jenis sanksi, yaitu tindakan, bagi pelaku tindak pidana yang berumur di bawah 14 tahun (Pasal 69 ayat (2) UU SPPA) dan Pidana, bagi pelaku tindak pidana yang berumur 14 tahun ke atas.

a. Sanksi Tindakan yang dapat dikenakan kepada anak meliputi (Pasal 82 UU SPPA):

- Pengembalian kepada orang tua/Wali;

- Penyerahan kepada seseorang;

- Perawatan di rumah sakit jiwa;

- Perawatan di LPKS;

- Kewajiban mengikuti pendidikan formal dan/atau pelatihan yang diadakan oleh pemerintah atau badan swasta;

- Pencabutan surat izin mengemudi; dan/atau

- Perbaikan akibat tindak pidana.

b. Sanksi Pidana

Sanksi pidana yang dapat dikenakan kepada pelaku tindak pidana anak terbagi atas Pidana Pokok dan Pidana Tambahan (Pasal 71 UU SPPA):

Pidana Pokok terdiri atas:

- Pidana peringatan;

- Pidana dengan syarat, yang terdiri atas: pembinaan di luar lembaga, pelayanan masyarakat, atau pengawasan;

- Pelatihan kerja;

- Pembinaan dalam lembaga;

- Penjara. 
- Pidana Tambahan terdiri dari:

- Perampasan keuntungan yang diperoleh dari tindak pidana; atau

- Pemenuhan kewajiban adat.

Selain itu, UU SPPA juga mengatur dalam hal anak belum berumur 12 (dua belas) tahun melakukan atau diduga melakukan tindak pidana, Penyidik, Pembimbing Kemasyarakatan, dan Pekerja Sosial Profesional mengambil keputusan untuk: (lihat Pasal 21 UU SPPA)

1) menyerahkannya kembali kepada orang tua/Wali; atau

2) mengikutsertakannya dalam program pendidikan, pembinaan, dan pembimbingan di instansi pemerintah atau LPKS di instansi yang menangani bidang kesejahteraan sosial, baik di tingkat pusat maupun daerah, paling lama 6 (enam) bulan.

\section{Hak-hak Anak}

Undang-undang sppa yang ada saat ini dianggap sebagai penyempurnaan dari aturan-aturan pendahulunya, baik yang ada dalam khup atau uu pengadilan anak. Hak-hak itu seperti masih bisa mengenyam pendidikan sampai selesai, mendapatkan pembekalan rohani religi, atau hak-hak lain yang semesti dan selaknya anak mendaptkannya. Hanya saja mendapat sanksi dan harus menjalaninya dalam lingkungan yang berbeda ${ }^{36}$.

Serta dalam Pasal 4 UU SPPA menyatakan bahwa anak yang sedang menjalani masa pidana berhak atas:

a. Remisi atau pengurangan masa pidana;

b. Cuti menjelang bebas;

c. Asimilasi;

36 Lihat pasal 3 UU SPPA beberapa hak anak: diperlakukan secara manusiawi, memperoleh bantuan hukum dan bantuan lain secara efektif, melakukan kegiatan rekreasional; bebas dari penyiksaan, penghukuman atau perlakuan lain yang kejam, tidak manusiawi, serta merendahkan derajat dan martabatnya;tidak dijatuhi pidana mati atau pidana seumur hidup; tidak ditangkap, ditahan, atau dipenjara, kecuali sebagai upaya terakhir dan dalam waktu yang paling singkat; memperoleh keadilan di muka pengadilan anak yang objektif, tidak memihak, dan dalam sidang yang tertutup untuk umum; tidak dipublikasikan identitasnya;memperoleh pendampingan orang tua/Wali dan orang yang dipercaya oleh anak; memperoleh aksesibilitas, terutama bagi anak cacat; memperoleh pendidikan;memperoleh pelayananan kesehatan; dan memperoleh hak lain sesuai dengan ketentuan peraturan perundang-undangan. 
d. Cuti bersyarat;

e. Cuti mengunjungi keluarga;

f. Pembebasan bersyarat;

g. Hak-hak lain sesuai dengan peraturan perundang-undangan.

\section{Penahanan}

Dalam khup kita, berkaitan masalah anak belum banyak menyediakan aturan atau prosedur yang lebih tentang bagaimana cara penahanan terhadap anak. Akan tetapi perlu diketahui bahwa dengan tersuratnya keistimewaan pada anak yang ada pada pasalpasal 45, 45, dan 47 kuhp memberikan indikasi utuk dilakukan penanganan ataupun penahanan yang sudah barang tentu secara manusiawia.

Kemudian menjadi sangat proporsional ketika keluar undang-unadang tentang pengadilan anak, yang memberi ketegasan pada upaya segala tentang anak harus dengan sebuah aturan dan mekanisme yang lebih baik, yakni pejabat atau penyidik, penuntut, ataupun hakim yang benar-benar khusus disediakan untuk menangani masalah anak, misal penyidik anak, penuntut umum anak dan juga hakim anak.

Pasal 32 ayat (2) UU SPPA menyatakan bahwa penahanan terhadap anak hanya dapat dilakukan dengan syarat anak telah berumur 14 (empat belas) tahun, atau diduga melakukan tindak pidana dengan ancaman pidana penjara tujuh tahun atau lebih. Jika masa penahanan sebagaimana yang disebutkan diatas telah berakhir, anak wajib dikeluarkan dari tahanan demi hukum.

\section{Pemeriksaan Terhadap Anak Sebagai Saksi atau Anak Korban}

Pada aturan-aturan pendahuluhunya belum banyak mengalami kemajuan berubahan yang lebih maju dari uu yang ada sekarang ini yakni belum sama sekali dicantumkan penyebutan anak sebagi saksi ataupun anak korban. Karena pada aturan pendahulu ini masih berkuat pada anak sebagai pelaku atau subyek hukum. Perkembangan ini baru bisa diketemukan pada uu sppa yang saat ini yang lebih rinci menyajiikan status posisi anak yang mempunyai konsekwensi hukumnya nanti.

UU SPPA ini memberikan kemudahan bagi anak saksi atau anak korban dalam memberikan keterangan di pengadilan.Saksi/korban yang tidak dapat hadir untuk memberikan keterangan didepan sidang pengadilan dengan alasan apapun dapat memberikan keterangan diluar sidang 
pengadilan melalui perekaman elektronik yang dilakukan oleh Pembimbing Kemasyarakatan setempat, dengan dihadiri oleh Penyidik atau Penuntut Umum, dan Advokat atau pemberi bantuan hukum lainnya yang terlibat dalam perkara tersebut. (lihat Pasal 58 ayat (3) UU SPPA).

\section{Hak Mendapatkan Bantuan Hukum}

Mulai dalam aturan Kuhp, undang-undang Pengadilan Anak, dan Sistem Peradilan Pidana Anak sama-sama memberikan upaya bantuan hukum bagi anak yang berhadapan atau berkonflik hukum tanpa mendiskriminasikannya. Hal ini mengisyaratkan bahwa sesorang individu yang bermasalah dengan hukum mendapatkan hak-hak pembelaan atau pendampingan hukum dari advokat atau lembaga bantuan hukum yang berkenan memberikan pendampingan secara tuntas sempai meraka mendapatkan sebuah keputusan.

Anak berhak mendapatkan bantuan hukum disetiap tahapan pemeriksaan, baik dalam tahap penyelidikan, penyidikan, penuntutan, maupun tahap pemeriksaan di pengadilan diatur dalam Pasal 23 UU SPPA.

\section{Lembaga Pemasyarakatan}

Baik Kuhp ataupun uu pengadilan anak dalam hal ini mengisyaratkan tentang adanya sebuah lembaga tersebut, cuman dalam hal penamaannya saja yang sedikit berbeda dengan yang ada sekarang ini. Lembaga pemasyarakatan inipun sebenarnya tidak bekerja sendiri terutama dalam menangani masalah anak yakni seperti kordinasi dengan bapas yang berperan penting dalam memberikan pertimbangan, saran-saran, advokasi, atau penelitian, yag akan sangat berguna bagi penentuan pengambilan diversi terhadap anak.

Dalam Pasal 86 ayat (1) UU SPPA, anak yang belum selesai menjalani pidana di Lembaga Pembinaan Khusus Anak (LPKA). Walaupun demikian, baik UU SPPA dan UU Pengadilan Anak sama-sama mengatur bahwa penempatan anak di Lembaga Pemasyarakatan dilakukan dengan menyediakan blok tertentu bagi mereka yang telah mencapai umur 18 (delapan belas) tahun sampai 21 (dua puluh satu) tahun (Penjelasan Pasal 86 ayat (2) UU SPPA dan Penjelasan Pasal 61 ayat (2) UU Pengadilan Anak). 


\section{Penutup}

Istilah mediasi dalam sistem peradilan kita bukan suatu hal yang baru ataupun lazim digunakan dalam lapana hukum perdata, beberapa Negara sudah banak mempergunakan mediasi dalam perkara pidana ang dipandang lebih harmonis dan sesuia dengan alam kebudayaan dalam menyelesaikan kasus-kasun hukum.

Walaupun pandangan ini masih dianggap sebagai "the third way atau the third path" sebagai upaya crime controland the criminal justice system" Dalam kenyataan kehidupan sehari-hari sering dijumpai cara-cara penyelesaian damai dan mediasi dalam kasus pidana yang dianggap sebagai local wisdom atau local jenius ide dasasr diatas inilah yang menjadi dasar bagi pembangunan penegakan hokum yang layak dikaji dan bermetaformosis dalam sebuah regulasi sistem peradilan pidana anak (SPPA) yang sarat akam pembaruan-pembaruan dalam hukum pidana anak dari pendahulunya.

Konsep pembaruan hukum merupakan upaya untuk merombak struktur hukum lama (hukum penjajah) yang pada umumnya dianggap eksploitatif dan diskriminatif. Sedang tuntutan pembangunan masyarakat memerlukan kerangka dalam pembaharuan dibidang hokum. Walaupun saat ini masih banyak peraturan-peraturan yang sudah tidak up-to date yang masih tetap dipertahankan. Hal inilah ang memerlukan revisi dan jika perlu harus dirubah totol dengan bobot materi yang mencerminkan gejala fenomena masyarakat saat ini.

Riwayat singkat penerapan model pembaruan kebijkan dalam berbagai regulasi perundang-undangan berkaitan anak dapat sedikit ulas yakni dalam, KUHP mengatur sistem pemidanaan terhadap anak, meliputi batas usia dibawah 16 tahun (minderjarig) sebagai orang yang dikategorikan anak sebagai pelaku tindak pidana, tanpa memberikan batas usia tertentu sehingga seolah-olah anak yang baru lahirpun dapat dimintai pertanggungjawaban pidana. Sedangkan masalah jenis sanksi yang diancamkan terhadap anak, selain mengatur ancaman sanksi pidana sebagaimana ditegaskan dalam Pasal 45,46, dan 47 KUHP (ketika masih berlaku) yang berupa pidana pokok dan pidana tambahan. KUHP mengatur pula jenis sanksi yang berupa tindakan, yeng meliputi; mengembalikan kepada orang tua/wali, dididik oleh negara tanpa pidana apapun, 
diserahkan kepada seseorang atau badan hukum, yayasan ataupun lembaga amal yang menyelenggarakan pendidikan (Pasal 45 dan 46 KUHP).

Dengan demikian ancaman terhadap anak menganut sistem dua jalur atau "Double Track System". Dilihat dari latar belakang kemunculan ide tersebut, dapat disimpulkan bahwa sistem tersebut adalah kesetaraan antara sanksi pidana dan sanksi tindakan. Ide kesetaraan ini dapat ditelusuri lewat perkembangan yang terjadi dalam sistem sanksi hukum pidana dari aliran klasik kealiran modern dan aliran neo-klasik.

Dengan hadirnya undang-undang sistem peradilan pidana anak hal yang baru, yaitu mengenai ditambahnya batas usia pertanggungjawaban anak menjadi $12 \mathrm{~s} / \mathrm{d} 14$ tahun untuk dikenai tindakan dan $14 \mathrm{~s} / \mathrm{d} 18$ tahun untuk tindak pidana penjara. Sebagaimana yang terdapat dalam pasal 69 (2) yang menyiratkan bahwa anak yang belum berusia 14 tahun "hanya" dapat dikenai tindakan dan hal ini harus kita pahami secara komprehensip serta mendalam mengenai sistem penerapan batas usia anak dalam lex spesialisis saat ini.

Masalahnya adalah apakah proses perubahan atau pembaharuan yang berlangsunng ini seseuai dengan kaidah nilainilai hukum yang ada dimasyarakat? Beberapa aturan mencoba meramu dan mengimplementasikan dalan sebuah kebijakan perundang-undangan serta terus berevolusi sesuai cermin kehidupan bangsa serta adat budaya yang berpegang teguh pada pancasila.

Dalam pengaturan uu SPPA ini, ada hal yang paling subtansial yang megatur secara tegas mengenai konsep keadilan restoratif terhadap anak yang berhadapan dengan hukum. Begitu pula maksud yang tertuang dalam kebijakan perundang-undang ini memberikan jalur alternatf bagi para penegak hukum, kelurga, korban, dan masyarakat sebisa mungkin mengupayakan proses penyelesaian diluar jalur sistem peradilan pidana sebagimana mestinya yakni dapat melalalui upaya diversi, yang berorientasi pada model pendekatan keadilan restoratif yakni penyelesian dengan mempertemuakan berbagai pihak untuk mencara jalan penelesaian mencari pemulihan dan menekankan pada upaya pembalasan. 
Dalam uu no 11 tahun 2012 tentang SPPA memberi petunjuk kuat tentang adanya mediasi penal. Walaupun undang-undang tidak secara tegas menggunakan istilah "mediasi" sehinggah model-model seperti ini belum banyak masyarakat yang memahami isi dan prosedur penerapannya.

Pemakaian konsep istilah diversi memang baru dan belum banyak populer serta belum banyak yang mengerti, apalagi yang selama ini bahwa dalam hal kebijakan hokum pidana tegas tidak menyebutkan. Konsep diversi yakni sebuah konsep yang berupaya mengalihkan suatu kasus dari prosedur formal ke proses informal, ini artinya memberikan peluang upaya dalam hal menyelesaikan terutama perkara anak-anak.

Kemudian yang jadi menarik adalah dimana undang-undang sppa ini tidak mampu berdiri sediri yang selalu berdampingan dengan undang-undang sebagi induknya misal kuhp sebagai lex generalisnya (aturan berbagai kejahatan) yang hanya memberi pedoman kejahatan yang diatur.

Jadi, jelas sudah bahwa revelensi ide mediasi mencocoki dalam kebijakan, baik dalam implementasi kebijakan internasional sebagaimana termaktub dalam UN SMR-JJ (Standar Minimum Rule Juvenile Justice/Beijing Rules) maupun perundang-undang yang berlaku saaat ini yakni SPPA no 11 tahun 2012. Ini adalah sebuah langkah reformasi dalam bidang hukum (penal refom/law reform) khusunnya berkaitan dengan soal pembangunan sistem hukum pidana sebagai tujuan menata ulang bangunan hukum yang sesuai dengan nilai-nilai budaya masyarakat suatu bangsa itu sendiri.

\section{Daftar Pustaka}

Achjani, Zulfa. Perkembangan Sistem Pemidanaan Dan Sistem Pemasyarakatan. Jakarta: Rajawali Pres, 2017.

Hadi Suprapto, Paulus. Peradilan restorative: Model Peradilan Anak di Indonesia masa Mendatang. Malang: Bayu Media.

Maidin Gultom. Perlindungan Hokum Terhadap Anak Dalam Sistem Peradilan Pidana Anak Di Indonesia. Jakarta: Refika Aditama, 2009.

Marlian. Perdilan Pidana Anak Di Indonesia (Pengembangan Konsep Dan Restoratif Justice. Bandung: Refika Aditama, 2011.

Nawawi Arif, Barda dan Muladi. Perbandingan Hukum Pidana. Bandung: Alumni, 1992. 
Nawawi Arif, Barda. Mediasi Penal: Penyelesaian Perkara Pidana Di Luar Pengadilan. Semarang: PT. Pustaka Magister, 2012.

Nawawi Arif, Barda. Perkembangan Asas Hukum Pidana Indonesia, Semarang: PT. Pustaka Magister.

Sholahuddin. Sistem Sanksi Dalam Hukum Pidana (Ide Dasar Double Track System dan Implementasinya. Jakarta: Rajawali Pers, 2004.

Sambas, Nandang. Pembaruan Sistem Pemidanaan. Jakarta: Graha Ilmu, 2010.

Sudarto. Hukum Pidana I. Semarang: Yayasan Sudarto, 1990.

Supeno, Hadi. Kriminalisasi Anak. Jakarta: PT. Gramedia Pustaka Utama, 2010.

Wahyudi, Setya. Diversi Dalam Sistem Peradilan Pidana Anak, Semarang: Undip Press, 2009.

\section{ARTIKEL DALAM JORNAL}

Syakirin, Ahmad. "Formulasi Model Sistem Peradilan Di Indonesia. "Mimbar Yustitia, Volume 2, No. 1 /2 2018.

Safudin, Endrik. "Politik Hukum Dikresi Di Indonesia." LPPM, 2019.

\section{PERATURAN PERUNDANG-UNDANGAN}

1. Kitab Undang-Undang Hukum Pidana (KUHP), Jakarta: Bumi Aksara. Muljatno

2. Kitab Undang-Undang Hukum Acara Pidana (KUHAP), Jakarta: Bumi Aksara. Muljatno

3. Undang-Undang No. 12 Tahun 1995 Tentang Pemasyarakatan

4. Undang-Undang No. 3 Tahun 1997 Tentang Pengadilan Anak (Diganti)

5. Undang-Undang No. 11 Tahun 2012 Tentang SistemPeradilan Pidana Anak ( UU Terbaru)

6. Kepres RI Nomer 36 Tahun 1990 Tentang Pengesahan Convention On The Rights of The Child ( Konvensi Tentang Hakhak Anak)/Konvensi-Konvensi PBB Tentang Anak. INSTRUMEN INTERNASIONAL

1. 1924 Geneva Declaration of the Rights of the Child

2. 1959 UN General Assembly Declaration on the Rights of the Child

3. 1966 International Convenant on Civil and rights of the Child 
4. 1966 International Convenant on Economic, Social, and Cultural Rights

5. 1985 UN Standar Minimum Rules For The Administration Of Juvenile Justice (Beijing Rules)

6. 1989 UN Convenan on the Rights of the Child 